\title{
Zinc Vaporization and Self-reduction Behavior of Industrial Waste Residues for Recycling to the Hlsarna Furnace
}

\author{
Timothy Kerry ${ }^{1}$ (D) Alexander Peters ${ }^{1} \cdot$ Evangelos Georgakopoulos $^{1} \cdot$ Iulian Dugulan $^{2} \cdot$ Koen Meijer $^{3}$. \\ Johannes Hage $^{3}$ - Erik Offerman ${ }^{1} \cdot$ Yongxiang Yang $^{1}$
}

Received: 4 May 2021 / Accepted: 6 September 2021 / Published online: 7 March 2022

(C) The Author(s) 2022

\begin{abstract}
Within the steelmaking industry, a large amount of zinc-bearing waste is produced which cannot be effectively treated through integrated steel mills. Concurrently, zinc smelters generate waste residues containing significant amounts of iron and zinc which are stored or landfilled. The zinc concentration of iron and steelmaking residues inhibits its recycling to the blast furnace but is insufficient to be sent directly to the zinc producers. Consequently, a means of up-concentration is required. The pilot HIsarna ironmaking furnace has shown potential for processing secondary iron-bearing resources. Furthermore, zinc can be concentrated in the off-gas flue dust, providing an enriched input for zinc smelters. The potential recyclability of blast furnace (BF) and basic oxygen furnace (BOF) dust and 'goethite' residue from the zinc industry has been studied. The input materials have been comprehensively characterized and their reduction-vaporization behavior, has been investigated. Individual samples were tested at temperatures of up to $1300^{\circ} \mathrm{C}$. Here, it was shown that minimal reduction of iron and volatilization of zinc occurred in the goethite and BOF samples. Conversely, even at $1000{ }^{\circ} \mathrm{C}$, the $\mathrm{BF}$ dust showed complete reduction of iron and removal of zinc within $30 \mathrm{~min}$. This was due to its high carbon content (40 wt\%) which can act as a reductant. Consequently, mixtures of BOF dust and goethite with BF dust were studied. It has been shown that mixtures of 30:70 $\mathrm{BF}$ dust to goethite and 20:80 BF dust to BOF dust are suitable for recovering zinc to the gas phase and fully reducing the contained iron.
\end{abstract}

The contributing editors for this article were Veena Sahajwalla and Bart Blanpain.

Timothy Kerry

T.J.Kerry@tudelft.nl

Yongxiang Yang

Y.Yang@tudelft.nl

1 Materials Science and Engineering, Delft University of Technology, Mekelweg 2, 2628 CD Delft, The Netherlands

2 Radiation Science and Technology, Delft University of Technology, Mekelweg 15, 2629 JB Delft, The Netherlands

3 Tata Steel Research and Development, PO Box 10000, 1970 CA IJmuiden, The Netherlands 


\section{Graphical Abstract}

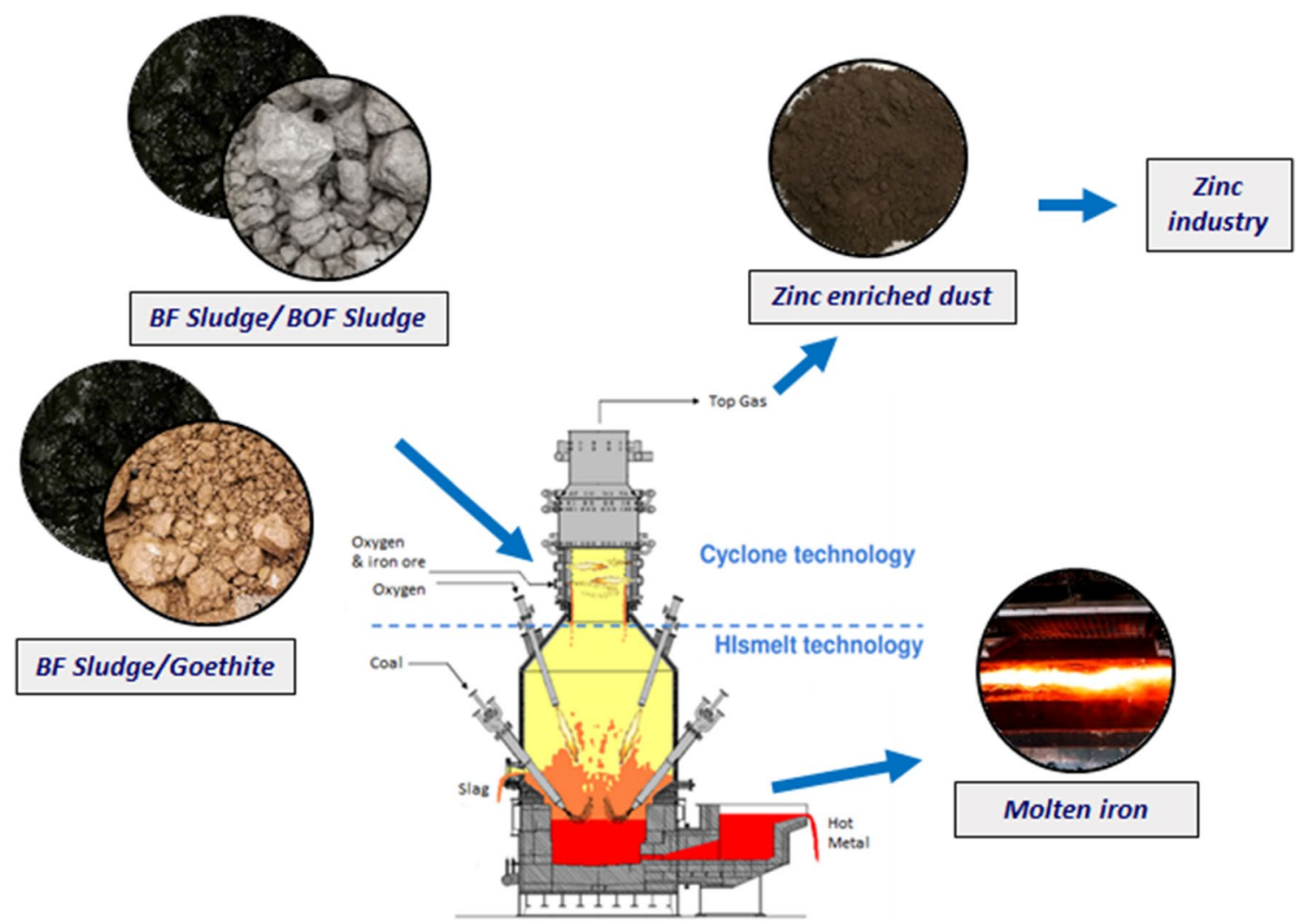

Keywords Recycling $\cdot$ Flue dusts $\cdot$ Self-reduction · HIsarna ironmaking

\section{Introduction}

The steelmaking industry makes use of zinc as a coating material for the production of galvanized steel. This imparts a corrosion resistance to the steel with the zinc being preferentially oxidized. The recycling of steel scrap either through the electric arc furnace (EAF) or integrated steel plant can lead to potential looping and accumulation of zinc. This can also occur due to the presence of small amounts within the iron ore and coal. In these industrial pyrometallurgical processes, this zinc will generally be volatilized at the high temperatures. Consequently, zinc in various oxidized forms can be found in the dusts and sludges captured within the off-gas systems. Together with the zinc, there are also appreciable quantities of other materials such as iron, slagging elements, and carbon. As a result, it is a valuable source of raw material for the process. However, when levels of zinc and other heavy metals become too high, operational problems can be observed in the integrated steelworks. The most problematic effect is the undermining of the furnace walls through $\mathrm{Zn}$ penetration, and through accretion of material, localized cyclic oxidation and reduction can take place [1]. Therefore, the zinc cycle within the steelmaking process must be tightly controlled. In general, a modern blast furnace operates with a maximum load of 100-150 g of zinc per ton of hot metal [2]. Consequently, dusts which are significantly concentrated in zinc must be kept in long-term storage or landfilled as a hazardous waste at appreciable cost [3, 4].

While supply risk associated with zinc is not currently considered to be critical [5], the use of secondary material in the zinc industry is expected to double by 2050 [6]. This is expected to come from both recycling galvanized steel scrap and also industrial residues, dusts, and sludges [6]. The zinc industry itself produces different waste streams containing appreciable quantities of zinc which can be considered for recycling. During leaching and iron removal, this waste appears in different forms such as jarosite, goethite, or haematite. These wastes from both steelmaking and zinc smelting can have a greatly varying quantity of zinc present with the maximum being found in EAF dust (up to $43 \mathrm{wt} \%$ ) [7]. Meanwhile, from the BF-BOF route, zinc values are more likely to be concentrated in the range of a few percent with an absolute maximum of $8-10 \mathrm{wt} \%[8,9]$. From zinc industry sources, this value can also reach up to around 9 
wt\% [10]. Regardless, from any of the sources described above, some extent of up-concentration of zinc will generally be required before it would be economically attractive to the zinc smelter [11]. While the Waelz kiln is a common means of concentrating zinc from EAF dusts, it is generally not used for BF/BOF dust. Furthermore, the contained iron is not recovered and large quantities of waste side streams are created. Consequently, an alternative treatment methodology for these lower $\mathrm{Zn}$-concentrated waste streams is desirable.

The HIsarna process is a novel ironmaking technology owned by Tata Steel that shows great potential for the recycling of zinc-bearing wastes. A pilot-scale facility of this technology has been functional at the Tata Steel site in IJmuiden, The Netherlands since 2010. Furthermore, a demonstration plant will be constructed in Jamshedspur, India in the near future. Pilot plant operation has shown that the furnace is highly suited to zinc and heavy metal recovery due to its great raw materials flexibility [12]. It has been seen that there is no limit to zinc concentration within the materials processed by HIsarna. Consequently, through the HIsarna process, it is possible to recycle steelmaking wastes and galvanized steel scrap. Moreover, waste materials from other industries can also be utilized such as zinc-leaching residues. Resultantly, the furnace contributes towards closing waste material loops from two separate industries (illustrated in Fig. 1). Comparative to the rotary hearth furnace, a metallic iron product is also produced in HIsarna that can go directly to the BOF, eliminating the need to process direct reduced iron in a BF.

Within this research, investigation has taken place into the behavior of three industrial by-products at high temperatures. Reduction of blast furnace (BF) dust and basic oxygen furnace (BOF) dust along with 'goethite' residue formed during zinc production have all been studied. Due to the high carbon content of BF dust, it has been observed to impart a self-reducing behavior $[4,13,14]$. Consequently, the possibility of using BF dust as a reductant in mixed dust samples has been studied, and the ideal ratio of dusts was investigated. Through understanding how to maximize the zinc vaporization efficiency, the concentration of zinc in the HIsarna off-gas system can be significantly increased. Furthermore, with efficient reduction of the contained iron in the wastes, the addition of coal to HIsarna can be minimized.
Fig. 1 Illustration of how HIsarna can operate regarding the recycling of zinc and closing of secondary material loops

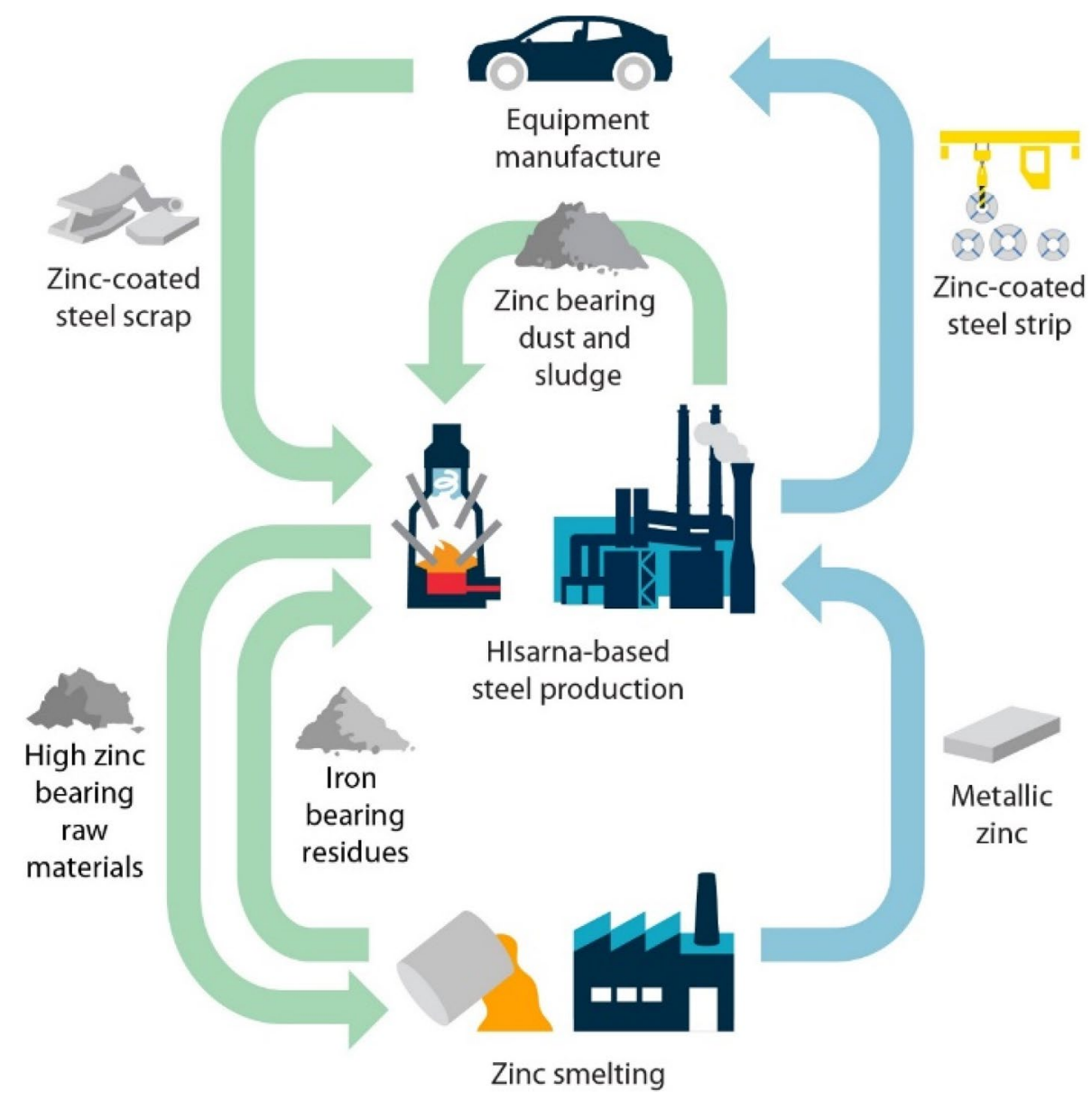




\section{Materials and Methods}

\section{Materials}

BF and BOF dust were received from Tata Steel Europe and 'goethite' residue from Nyrstar (Fig. 2). Prior to characterization and experimentation, the wet material was dried overnight in a furnace at $120^{\circ} \mathrm{C}$.

Laser granulometric size analysis was undertaken using a Microtrack S3500 in water, both with and without the use of ultrasound dispersion. The elemental compositions of these starting materials were determined using an Axios Max wavelength dispersive X-ray fluorescence (WD-XRF) in oxides mode and LECO C/S 744 analysis (for carbon and sulfur). X-ray diffraction (XRD) analysis was conducted using a Bruker D8 Advance diffractometer for investigating the mineralogy of the samples. It is not possible to distinguish magnetite from franklinite through XRD analysis due to them showing the same crystal structure and similar lattice parameters $[15,16]$.

Consequently, Mössbauer spectroscopy was undertaken to provide a clearer value of franklinite content. Furthermore, quantifiable contents of all iron phases can be calculated using this technique. Transmission ${ }^{57} \mathrm{Fe}$ Mössbauer spectra were collected at 300 and $4.2 \mathrm{~K}$ with conventional constant acceleration or sinusoidal velocity spectrometers using a ${ }^{57} \mathrm{Co}(\mathrm{Rh})$ source. Velocity calibration was carried out using an $\alpha$-Fe foil at room temperature. The Mössbauer spectra were fitted using the Mosswinn 4.0 program [17]. Thermodynamic calculations were performed using HSC Chemistry v6.12 Thermochemical Database, and from this, the likelihood of possible reactions taking place could be assessed [18].

\section{Methodology}

Experiments were conducted in a Carbolite STF 16/50/450 horizontal furnace (schematic shown in Fig. 3) at $850{ }^{\circ} \mathrm{C}$, $1000{ }^{\circ} \mathrm{C}$, and $1300{ }^{\circ} \mathrm{C}$. A flow ( 2 standard $1 / \mathrm{min}$ ) of inert gas $\left(\mathrm{N}_{2}\right.$ or $\left.\mathrm{Ar}\right)$ was maintained across the reaction tube. Dust samples $(2-5 \mathrm{~g})$ were introduced to the furnace in alumina boat crucibles. These were held in a water-cooled flange prior to introduction to the hot zone at appropriate temperature. Samples remained in the isothermal zone for the desired retention time, ranging from 1 to $30 \mathrm{~min}$. In the case of samples at $1300{ }^{\circ} \mathrm{C}$, this was limited to $10 \mathrm{~min}$. Once the experiment had been completed, the samples were quenched by pulling the crucible back in to the water-cooled flange. Weight changes were recorded before and after heating. On-line continuous off-gas analysis was conducted using a Hiden Analytical HPR-20 R\&D mass spectrometer. Experimental parameters were chosen to probe the fundamental behavior of the individual and mixed dusts. Further experiments probing the dust behavior in conditions more reflective of the HIsarna reactor will be conducted in future studies.

Mixtures of 'goethite' and BOF dust with BF dust were prepared in varying ratios. Principally, the amount of $\mathrm{BF}$ dust required was calculated based upon the stoichiometric

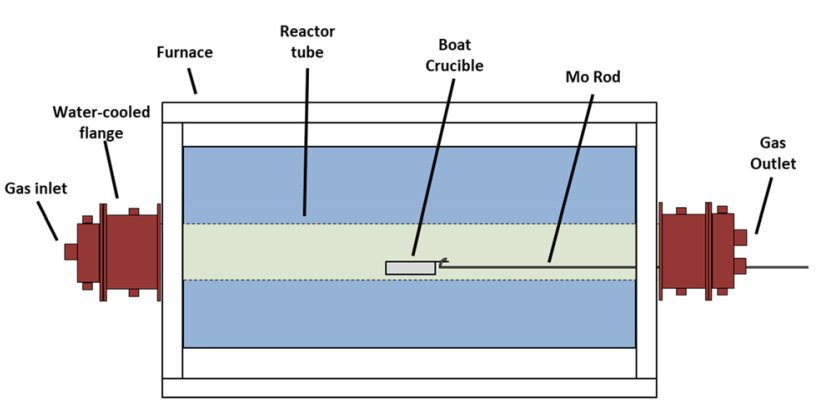

Fig. 3 Experimental setup showing horizontal furnace used for high-temperature experiments under controlled gas atmosphere
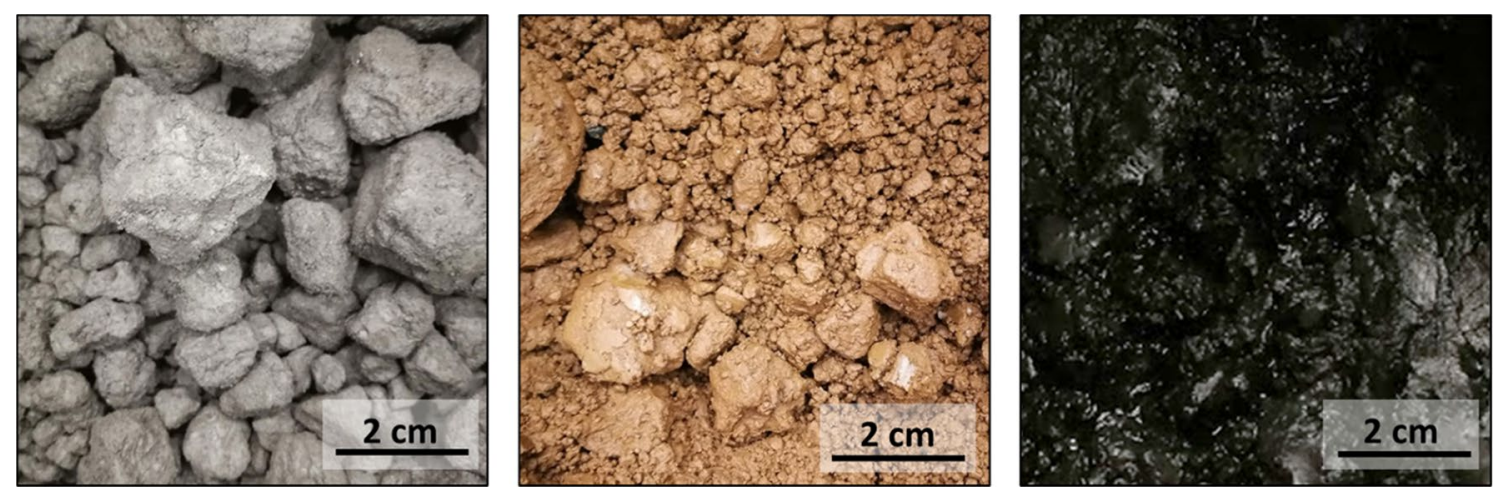

Fig. 2 As-received material in the wet form, from left-to-right BOF dust, goethite, and BF sludge 
quantity of carbon required to fully reduce the contained zinc and iron within the materials. Consequently, ratios of 35:65 (BF/BOF dust) and 37:63 (BF dust/goethite) were identified. However, the calculation of these values necessitated two assumptions. First, it was assumed that the reduction reactions taking place were solely occurring between the solid carbon and the oxides (i.e., Reactions 1-5). Potential reactions with the produced $\mathrm{CO}$ were ignored; thus, an overestimate of required $\mathrm{C}$ is possible. Second, reactions of species other than iron and zinc with carbon were not taken in to account. Resultantly, by ignoring potential reactions (such as Reaction 6), this could result in underestimation of required carbon.

$\mathrm{Fe}_{3} \mathrm{O}_{4}+\mathrm{C} \rightarrow 3 \mathrm{FeO}+\mathrm{CO}_{(\mathrm{g})} \quad \Delta_{\mathrm{r}} G^{\circ\left(1000^{\circ} \mathrm{C}\right)}=-59 \mathrm{~kJ} \mathrm{~mol}^{-1}$,

$\mathrm{Fe}_{2} \mathrm{O}_{3}+\mathrm{C} \rightarrow 2 \mathrm{FeO}+\mathrm{CO}_{(\mathrm{g})} \quad \Delta_{\mathrm{r}} G^{\circ\left(1000^{\circ} \mathrm{C}\right)}=-95 \mathrm{~kJ} \mathrm{~mol}^{-1}$,

$\mathrm{FeO}+\mathrm{C} \rightarrow \mathrm{Fe}+\mathrm{CO}_{(\mathrm{g})} \quad \Delta_{\mathrm{r}} G^{\circ\left(1000^{\circ} \mathrm{C}\right)}=-43 \mathrm{~kJ} \mathrm{~mol}^{-1}$,

$3 \mathrm{ZnFe}_{2} \mathrm{O}_{4}+\mathrm{C} \rightarrow 3 \mathrm{ZnO}+2 \mathrm{Fe}_{3} \mathrm{O}_{4}+\mathrm{CO}_{(\mathrm{g})} \quad \Delta_{\mathrm{r}} G^{\circ\left(1000^{\circ} \mathrm{C}\right)}$ $=-82 \mathrm{~kJ} \mathrm{~mol}^{-1}$,

$\mathrm{ZnO}+\mathrm{C} \rightarrow \mathrm{Zn}+\mathrm{CO}_{(\mathrm{g})} \quad \Delta_{\mathrm{r}} G^{\left({ }^{\circ} 1000^{\circ} \mathrm{C}\right)}=-15 \mathrm{~kJ} \mathrm{~mol}^{-1}$,

$\mathrm{PbSO}_{4}+\mathrm{CaO}+\mathrm{C} \rightarrow \mathrm{Pb}+\mathrm{CaSO}_{4}+\mathrm{CO}(\mathrm{g}) \quad \Delta_{\mathrm{r}} G^{\circ}\left(1000^{\circ} \mathrm{C}\right)$ $=-219 \mathrm{~kJ} \mathrm{~mol}^{-1}$.

In order to balance against the possible under-/overestimation described above, tests were performed in 20:80, 40:60, and 60:40 ratios of BF dust to goethite or BOF dust.

\section{Results and Discussion}

\section{Material Characterization}

\section{Particle Size Analysis}

Moisture content of the as-received material was measured and is shown in Table 1. BF dust and goethite have 48 and $40 \mathrm{wt} \%$ moisture (wet-basis), respectively; the BOF dust is lower at $24 \mathrm{wt} \%$. Once dried, the material remained in distinct agglomerates, and resultantly particle size analysis of the material both with and without ultrasonication was undertaken. It can be seen from the results in Table 1 that the ultrasonication had great impact on breaking down the larger agglomerates into discrete particles. Once dispersed all materials showed very small particle size and minimal distribution. The $D_{90}$ in every case was less than $40 \mu \mathrm{m}$. The small particle size can be a positive factor as grinding should not be necessary prior to recycling pyrometallurgically, although some agglomeration may be necessary.

\section{Chemical Analysis}

Elemental analysis of the as-received materials took place using XRF spectroscopy and LECO analysis (Table 2), the latter for carbon and sulfur measurements. The nature of the dusts varies greatly; in both the BOF dust and goethite, the major component is iron (recorded as $\mathrm{Fe}_{2} \mathrm{O}_{3}$ ) with 84.1 $\mathrm{wt} \%$ and $52.1 \mathrm{wt} \%$, respectively. Meanwhile, the BF dust has a reasonably high iron oxide content of $33.3 \mathrm{wt} \%$ but a more significant level of carbon $(41.3 \mathrm{wt} \%)$, the latter is much lower in the other materials. This carbon is of significant relevance to the study as it can act as a reductant
Table 1 Measured moisture content of the as-received materials and particle size distribution of materials measured by laser granulometry

\begin{tabular}{|c|c|c|c|c|c|c|c|}
\hline & $D_{10}(\mu \mathrm{m})$ & $D_{50}(\mu \mathrm{m})$ & $D_{90}(\mu \mathrm{m})$ & $D_{10}(\mu \mathrm{m})$ & $D_{50}(\mu \mathrm{m})$ & $D_{90}(\mu \mathrm{m})$ & $\begin{array}{l}\text { Moisture } \\
\text { content } \\
(\mathrm{wt} \%)\end{array}$ \\
\hline & $\begin{array}{l}\text { (with ultra- } \\
\text { sonification) }\end{array}$ & & & $\begin{array}{l}\text { (without ultra- } \\
\text { sonification) }\end{array}$ & & & \\
\hline BF dust & 7 & 10 & 20 & 10 & 47 & 159 & 48 \\
\hline BOF dust & 5 & 7 & 11 & 4 & 7 & 72 & 24 \\
\hline Goethite & 5 & 18 & 37 & 7 & 25 & 54 & 40 \\
\hline
\end{tabular}

Table 2 Initial composition of dusts after drying (C and S measured with LECO, rest with XRF)

\begin{tabular}{|c|c|c|c|c|c|c|c|c|c|c|c|c|c|c|}
\hline & $\begin{array}{l}\mathrm{C} \\
(\mathrm{wt} \%)\end{array}$ & $\begin{array}{l}\mathrm{S} \\
(\mathrm{wt} \%)\end{array}$ & $\begin{array}{l}\mathrm{Fe}_{2} \mathrm{O}_{3} \\
(\mathrm{wt} \%)\end{array}$ & $\begin{array}{l}\mathrm{ZnO} \\
(\mathrm{wt} \%)\end{array}$ & $\begin{array}{l}\mathrm{SiO}_{2} \\
(\mathrm{wt} \%)\end{array}$ & $\begin{array}{l}\mathrm{CaO} \\
(\mathrm{wt} \%)\end{array}$ & $\begin{array}{l}\mathrm{MgO} \\
(\mathrm{wt} \%)\end{array}$ & $\begin{array}{l}\mathrm{Al}_{2} \mathrm{O}_{3} \\
(\mathrm{wt} \%)\end{array}$ & $\begin{array}{l}\mathrm{MnO} \\
(\mathrm{wt} \%)\end{array}$ & $\begin{array}{l}\mathrm{P}_{2} \mathrm{O}_{5} \\
(\mathrm{wt} \%)\end{array}$ & $\begin{array}{l}\mathrm{PbO} \\
(\mathrm{wt} \%)\end{array}$ & $\begin{array}{l}\mathrm{K}_{2} \mathrm{O} \\
(\mathrm{wt} \%)\end{array}$ & $\begin{array}{l}\mathrm{CdO} \\
(\mathrm{wt} \%)\end{array}$ & $\begin{array}{l}\mathrm{As}_{2} \mathrm{O}_{3} \\
(\mathrm{wt} \%)\end{array}$ \\
\hline BF dust & 41.3 & 2.32 & 33.3 & 4.8 & 5.3 & 2.3 & 0.9 & 2.8 & 0.1 & 0.2 & 1.1 & 0.9 & 0.029 & - \\
\hline BOF dust & 2.4 & 0.09 & 84.1 & 0.6 & 1.3 & 8.5 & 1.4 & 0.1 & 0.9 & 0.1 & - & - & - & - \\
\hline Goethite & 0.21 & 12.06 & 52.1 & 9.4 & 4.1 & 9.3 & - & 2 & 0.7 & - & 3.3 & 0.1 & 0.043 & 0.6 \\
\hline
\end{tabular}


in reactions to reduce iron and zinc oxides (Reactions 1-5). Insufficient carbon is present in BOF dust and goethite for these self-reduction reactions to take place to completion; hence, mixtures with BF dust were investigated. From other industrial sources, the carbon content can vary in BF and BOF dust with a wide range exhibited in the literature [8, $14,19]$. Conversely, by the nature of the process, goethite waste will always contain little carbon and so another source of reductant will be required [20,21].

Zinc is present in all samples to varying degrees. The lowest concentration is in the BOF dust is $0.6 \mathrm{wt} \%$ while in $\mathrm{BF}$ dust and goethite, the zinc content is more appreciable (4.8 and $9.4 \mathrm{wt} \%$ ). The values of zinc concentration in these wastes will vary from plant to plant with different processes. While the concentration is low in BOF dust but high in BF dust in this case, the situation can be more similar or even reversed in other operations (primarily based on use of steel scrap in the BOF) [14, 16, 22]. Consequently, other sources of BOF dust may be more valuable for the goal of zinc recovery. Slagging material such as fluxes can also be recovered from these three secondary materials with reasonable concentrations of $\mathrm{CaO}$ and $\mathrm{SiO}_{2}$ (particularly in goethite) and smaller amounts of $\mathrm{MgO}$ and $\mathrm{Al}_{2} \mathrm{O}_{3}$ present. $\mathrm{A}$ potential problematic element in the goethite sample is the quantity of sulfur which can contaminate the hot metal [23].

\section{Mineralogical Analysis}

The phases present in the secondary material can have a great impact on the high-temperature behavior; thus, mineralogical study took place using XRD (results in Table 3; Fig. 4). Many different forms of iron are seen across the three samples. The most complex mixture is seen in BOF dust. The presence of metallic iron, wüstite $(\mathrm{FeO})$, and magnetite $\left(\mathrm{Fe}_{3} \mathrm{O}_{4}\right)$ were all observed along with a small amount of iron carbide $\left(\mathrm{Fe}_{3} \mathrm{C}\right)$. BOF dust is primarily generated during the oxygen blow and occurs through multiple

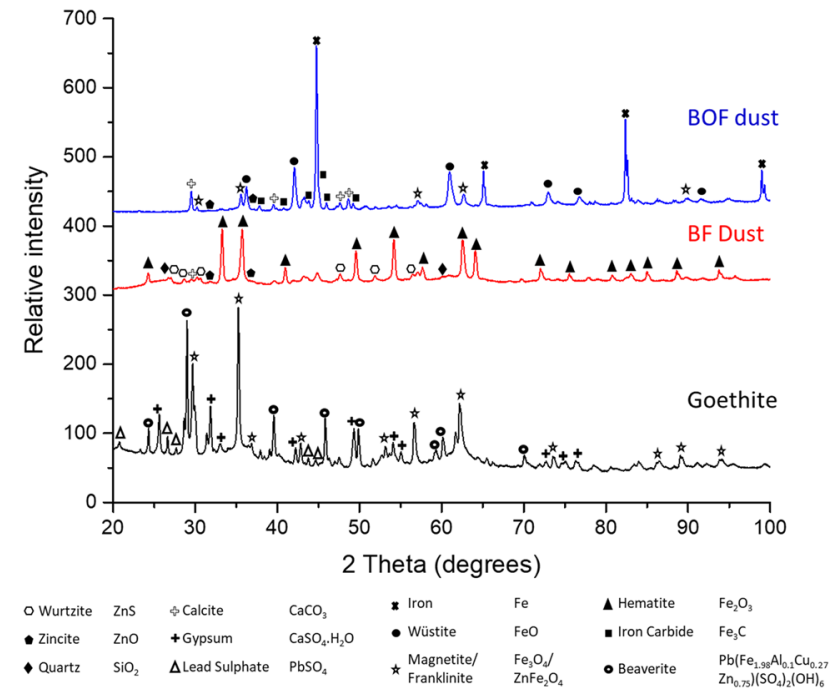

Fig. 4 XRD diffractograms of received materials

mechanisms, and this leads to the presence of multiple oxidation states of iron present in the off-gas system [24]. In the $\mathrm{BF}$ dust, iron was primarily hematite originating from the ore. Finally, in the case of goethite, the only crystalline phase containing iron that could be identified was provisionally that of franklinite. Here, it was concluded that the presence of magnetite was not feasible within the goethite sample and so the peaks could only be indicative of franklinite. The XRD spectra (Fig. 4) also show two wide, amorphous peaks indicating the presence of a poorly crystalline species. With comparison to the literature, it was seen that these broad peaks could be representative of ferrihydrite [25]. Ferrihydrite $\left.\left(\mathrm{Fe}_{2} \mathrm{O}_{3} \cdot 0.5 \mathrm{H}_{2} \mathrm{O}\right)\right)$ is an iron oxide that can be formed in the production of 'goethite' industrially $[10,26]$. However, it is generally a metastable material that will break down in order to form goethite or hematite $[27,28]$. To further investigate the iron
Table 3 Major phases present in the waste materials determined with XRD

\begin{tabular}{llllll}
\hline BF dust & & BOF dust & & Goethite & \\
\hline Haematite & $\mathrm{Fe}_{2} \mathrm{O}_{3}$ & Iron & $\mathrm{Fe}$ & Franklinite & $\mathrm{ZnFe}_{2} \mathrm{O}_{4}$ \\
Zincite & $\mathrm{ZnO}$ & Wustite & $\mathrm{FeO}$ & Ferrihydrite & $\mathrm{Fe}_{2} \mathrm{O}_{3} \cdot 0.5 \mathrm{H}_{2} \mathrm{O}$ \\
Quartz & $\mathrm{SiO}_{2}$ & Zincite & $\mathrm{ZnO}$ & Galena & $\mathrm{PbSO}_{4}$ \\
Calcite & $\mathrm{CaCO}_{3}$ & Magnetite & $\mathrm{Fe}_{3} \mathrm{O}_{4}$ & Gypsum & $\mathrm{CaSO}_{4} \cdot 2 \mathrm{H}_{2} \mathrm{O}$ \\
Wurtzite & $\mathrm{ZnS}$ & Calcite & $\mathrm{CaCO}_{3}$ & Beaverite & $\mathrm{Pb}\left(\mathrm{Fe}_{1.98} \mathrm{Al}_{0.1} \mathrm{C}\right.$ \\
& & & & & $\left.\mathrm{u}_{0.27} \mathrm{Zn}_{0.75}\right)$ \\
& & & & $\left(\mathrm{SO}_{4}\right)_{2}(\mathrm{OH})_{6}$ \\
& & Iron carbide & $\mathrm{Fe}_{3} \mathrm{C}$ & & \\
\hline
\end{tabular}


mineralogy of the tested samples, Mössbauer spectroscopy was conducted.

${ }^{57} \mathrm{Fe}$ Mössbauer spectroscopy can be used to investigate the oxidation state and coordination environment of ironbearing minerals and has been used in the study of ironbearing dusts previously $[10,15,16]$. In this study, samples were initially run at $300 \mathrm{~K}$, and at this temperature,

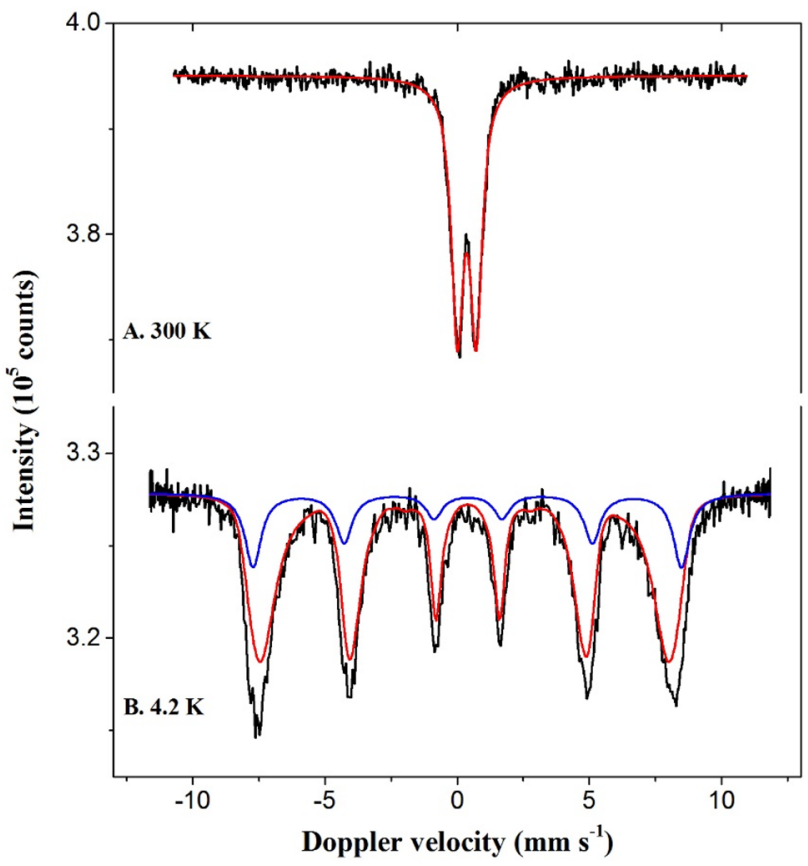

the goethite spectrum showed a characteristic $\mathrm{Fe}^{3+}$ doublet (Fig. 5). This was attributed to the presence of very small, superparamagnetic structures, and further assignment was not possible. Consequently, deconvolution was attempted by measuring the sample at $4.2 \mathrm{~K}$ (Fig. 5).

The spectral contributions which are obtained at $4.2 \mathrm{~K}$ are closer to reality due to the difference in the Debye temperature (lattice strength measure) of the Fe species present. It was determined that $23 \mathrm{wt} \%$ of the iron present was in the form of franklinite while the remaining $77 \mathrm{wt} \%$ was ferrihydrite in the goethite residue (Table 4). It has been suggested by Loan et al. (2002) that the ferrihydrite is stabilized by silica adsorption or by rapid precipitation, thus, inhibiting transformation in to goethite [26].

The quantity of zinc in franklinite and wurtzite was calculated using Eqs. 7-10:

$$
\begin{aligned}
& \mathrm{wt} \% \mathrm{Fe}_{\left(\mathrm{ZnFe}_{2} \mathrm{O}_{4}\right)}=\frac{\mathrm{wt} \% \mathrm{Fe}_{(\text {sample })} \times(\mathrm{M} \ddot{\text { ssbauer }}) \mathrm{wt} \% \mathrm{Fe}_{\left(\mathrm{ZnFe}_{2} \mathrm{O}_{4}\right)}}{100}, \\
& \mathrm{wt} \% \mathrm{ZnFe}_{2} \mathrm{O}_{4 \text { (sample) }}=\frac{\mathrm{wt} \% \mathrm{Fe}_{\left(\mathrm{ZnFe}_{2} \mathrm{O}_{4}\right)} \times M_{\left(\mathrm{ZnFe}_{2} \mathrm{O}_{4}\right)}}{M_{\mathrm{Fe}_{(}\left(\mathrm{ZnF}_{2} \mathrm{O}_{4}\right)}}, \\
& \mathrm{wt} \% \mathrm{Zn}_{\left(\mathrm{ZnFe}_{2} \mathrm{O}_{4}\right)}=\frac{\mathrm{wt} \% \mathrm{ZnFe}_{2} \mathrm{O}_{4(\text { sample })} \times M_{\mathrm{Zn}_{\left(\mathrm{ZnFe}_{2} \mathrm{O}_{4}\right)}}}{M_{\left(\mathrm{ZnFe}_{2} \mathrm{O}_{4}\right)}}, \\
& \mathrm{wt} \% \mathrm{Zn}_{(\mathrm{ZnS})}=\mathrm{wt} \% \mathrm{Zn}_{\text {(sample) }}-\mathrm{wt} \% \mathrm{Zn}_{\left(\mathrm{ZnFe}_{2} \mathrm{O}_{4}\right)} \text {. }
\end{aligned}
$$

\begin{tabular}{|c|c|c|c|c|c|c|}
\hline Sample/treatment & IS $\left(\mathrm{mm} \cdot \mathrm{s}^{-1}\right)$ & $\mathrm{QS}\left(\mathrm{mm} \cdot \mathrm{s}^{-1}\right)$ & $\begin{array}{l}\text { Hyperfine field } \\
\text { (T) }\end{array}$ & $\Gamma\left(\mathrm{mm} \cdot \mathrm{s}^{-1}\right)$ & Phase & $\begin{array}{l}\text { Spectral } \\
\text { contribution } \\
(\%)\end{array}$ \\
\hline \multirow[t]{2}{*}{ BF dust } & 0.35 & -0.19 & $51.0^{\mathrm{a}}$ & 0.28 & $\alpha-\mathrm{Fe}_{2} \mathrm{O}_{3}$ & 66 \\
\hline & 0.37 & 0.75 & - & 0.53 & $\mathrm{Fe}^{3+}(\mathrm{SPM})^{\mathrm{b}}$ & 34 \\
\hline \multirow[t]{6}{*}{ BOF dust } & 0 & - & 33 & 0.29 & $\mathrm{Fe}^{0}$ & 29 \\
\hline & 0 & - & - & 0.8 & $\mathrm{Fe}^{0}(\mathrm{SPM})^{\mathrm{b}}$ & 12 \\
\hline & 0.2 & - & 20.8 & 0.46 & $\theta-\mathrm{Fe}_{3} \mathrm{C}$ & 15 \\
\hline & 0.98 & 0.66 & - & 0.58 & $\mathrm{Fe}^{2+}(\mathrm{FeO})$ & 29 \\
\hline & 0.33 & - & 49.3 & 0.4 & $\mathrm{Fe}_{3} \mathrm{O}_{4}(\mathrm{I})$ & 6 \\
\hline & 0.65 & - & 44.6 & 0.88 & $\mathrm{Fe}_{3} \mathrm{O}_{4}(\mathrm{II})$ & 9 \\
\hline Goethite & 0.36 & 0.71 & - & 0.54 & $\mathrm{Fe}^{3+}(\mathrm{SPM})^{\mathrm{b}}$ & 100 \\
\hline \multirow[t]{2}{*}{ Goethite (at $4.2 \mathrm{~K}$ ) } & 0.34 & -0.12 & $45.8^{\mathrm{a}}$ & 0.41 & \multirow[t]{2}{*}{ Ferrihydrite $\mathrm{ZnFe}_{2} \mathrm{O}_{4}$} & 77 \\
\hline & 0.39 & -0.03 & 50.4 & 0.74 & & 23 \\
\hline
\end{tabular}

Fig. 5 Mössbauer spectra obtained at 300 and $4.2 \mathrm{~K}$ of 'goethite'

Table 4 The Mössbauer fitted parameters of dust samples, obtained at $300 \mathrm{~K}$ unless stated

Experimental uncertainties: isomer shift, IS $\pm 0.02 \mathrm{~mm} \mathrm{~s}^{-1}$; quadrupole splitting, $\mathrm{QS} \pm 0.02 \mathrm{~mm} \mathrm{~s}^{-1}$; line width, $\Gamma \pm 0.03 \mathrm{~mm} \mathrm{~s}-1$; hyperfine field $\pm 0.1 \mathrm{~T}$; spectral contribution $\pm 3 \%$

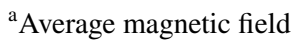

${ }^{\mathrm{b}}$ Very small, superparamagnetic, structures $(<10-15 \mathrm{~nm})$ 
The terms used above refer to wt $\% \mathrm{Fe}_{\left(\mathrm{ZnFe}_{2} \mathrm{O}_{4}\right)}$ is the weight percentage of iron in franklinite, and similarly, wt $\%$ $\mathrm{Fe}_{\text {(sample) }}$ is the weight percentage of iron in the total sample from XRF. (Mössbauer) wt\% $\mathrm{Fe}_{\left(\mathrm{ZnFe}_{2} \mathrm{O}_{4}\right)}$ is the weight percentage of iron in franklinite based on Mössbauer analysis of the total iron content. wt $\% \mathrm{ZnFe}_{2} \mathrm{O}_{4 \text { (sample) }}$ is the calculated weight percentage of franklinite in the total sample and $M_{\left(\mathrm{ZnFe}_{2} \mathrm{O}_{4}\right)}$ is the molar mass of franklinite. $M_{\mathrm{Fe}\left(\mathrm{ZnFe}_{2} \mathrm{O}_{4}\right)}$ is the molar mass of iron within franklinite, and wt $\% \mathrm{Zn}_{\left(\mathrm{ZnFe}_{2} \mathrm{O}_{4}\right)}$ is the weight percentage of zinc in franklinite. $M_{\mathrm{Fe}\left(\mathrm{ZnFe}_{2} \mathrm{O}_{4}\right)}$ is the molar mass of zinc in franklinite, $w t \% \mathrm{Zn}_{(\mathrm{ZnS})}$ is the weight percentage of $\mathrm{Zn}$ in $\mathrm{ZnS}$, and finally, wt $\% \mathrm{Zn}_{\text {(sample) }}$ is the weight percentage of zinc in the total sample from XRF.

From these calculations, it can be shown that in the goethite sample, $7 \mathrm{wt} \%$ of the zinc content is in the form of franklinite while $2.4 \mathrm{wt} \%$ is primarily $\mathrm{ZnS}$. The latter is a cautious designation as $\mathrm{ZnS}$ was the only other zinc-bearing phase identified in the XRD. However, there may be other phases present at concentrations beneath the limits of detection of the technique or that are amorphous in structure. The observation of the presence of franklinite and wurtzite agrees with what is seen in the literature [10, 21]. Highly insoluble franklinite is present from the roasting process while $\mathrm{ZnS}$ is added as a reductant for the iron during the goethite process [29].

The presence of franklinite could not be confirmed in the Mössbauer spectra of the BF or BOF dust. In the former, this is to be expected but the latter has previously been shown to contain franklinite $[16,30]$. In this case, the identification could be inhibited due to the low zinc concentration present and complex Mössbauer spectrum. The deconvolution of the spectra does reveal the presence of the iron-bearing phases (Table 4) also observed in the XRD (Table 3) and provides a ratio between these. The iron content of the BF dust is shown to be $66 \%$ hematite and $34 \%$ very small, superparamagnetic structures in the $\mathrm{Fe}^{3+}$ oxidation state. Coupling these results to the XRD spectrum, we can assume that the only phase present is hematite. BOF dust, on the other hand, has appreciable iron content in different oxidation states. The greatest proportion of the iron is either in the metallic or wüstite form, $41 \%$ and $29 \%$ of the total Fe content, respectively. Following this, $15 \%$ is iron carbide and the other $15 \%$ is magnetite.

Based upon XRD analysis, the zinc that is present in the $\mathrm{BF}$ dust is primarily in the form of $\mathrm{ZnS}$ with a small proportion of $\mathrm{ZnO}$. A very weak signal for $\mathrm{ZnO}$ was identified in the BOF dust diffractogram; furthermore, franklinite may be present, but this can be obscured in the XRD due to the presence of magnetite.

\section{Reduction Behavior of Individual Dust Samples at Varying Temperature}

Initially, individual samples were introduced to the horizontal furnace at $850{ }^{\circ} \mathrm{C}, 1000{ }^{\circ} \mathrm{C}$, and $1300{ }^{\circ} \mathrm{C}$ in an inert atmosphere for residence times of up to $30 \mathrm{~min}$. The weight of the material before and after furnace treatment were recorded, and characterization was conducted. The mass changes observed on the various samples are shown in Fig. 6.

BOF dust showed the least change in mass across all temperatures tested. At $850{ }^{\circ} \mathrm{C}$, the weight of the BOF dust appears to remain relatively stable over the $30 \mathrm{~min}$ exposure; however, this does not reflect a lack of reactions taking place. As can be seen at timescales below ten minutes, the sample actually gains weight (maximum 2.5\%), similarly before $2 \mathrm{~min}$ at $1000^{\circ} \mathrm{C}$. This can primarily be ascribed to reactions taking place outside the furnace. Upon removal, the sample had not fully cooled, and this allowed for oxidation of the contained iron. Visually this could be observed by areas of the sample turning red after air exposure, hence, the formation of hematite. Balancing against this observed weight gain, some elements were lost from the dust. The small quantity of carbon ( $2.4 \mathrm{wt} \%)$ contained in the material was rapidly oxidized in reactions most likely with iron but potentially also $\mathrm{Ca}, \mathrm{Mg}$, and $\mathrm{Zn}$. The latter can lead to volatilization of these species. In the case of the $850{ }^{\circ} \mathrm{C}$ BOF sample, this leads to a balance between the reduction and vaporization of material against the re-oxidation upon furnace removal. XRD analysis at $1000{ }^{\circ} \mathrm{C}$ shows that

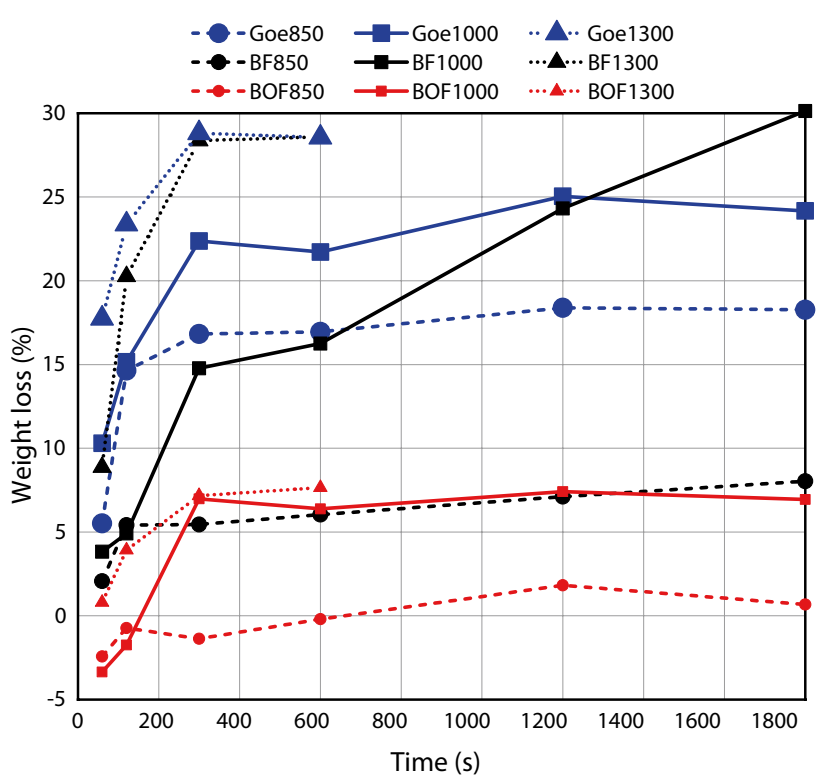

Fig. 6 Weight loss (\%) of industrial waste dusts after holding at $850{ }^{\circ} \mathrm{C}$ or $1000{ }^{\circ} \mathrm{C}$ in inert atmosphere over various retention times. Goe goethite, $B F$ blast furnace dust, $B O F$ basic oxygen furnace dust 


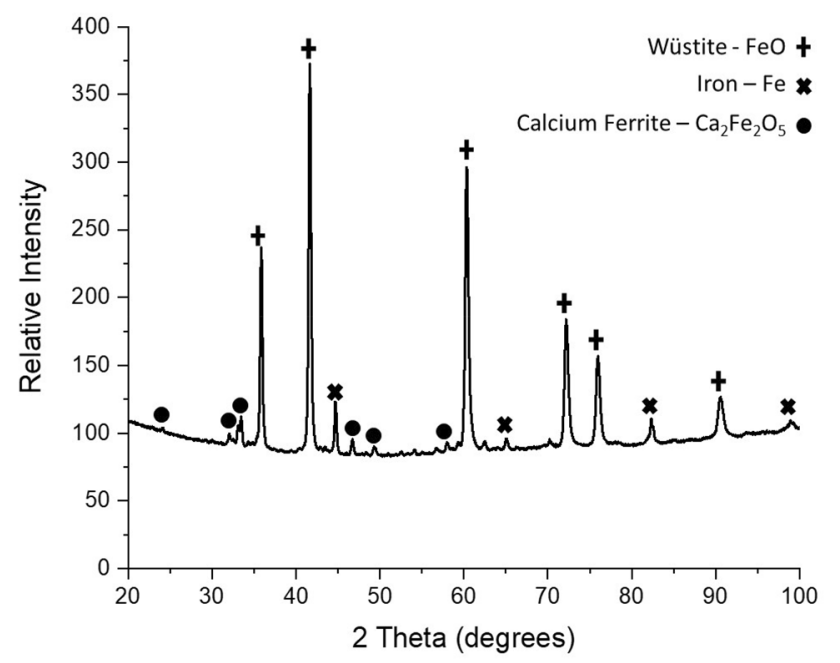

Fig. 7 XRD diffractogram of $\mathrm{BOF}$ held at $1000^{\circ} \mathrm{C}$ for $30 \mathrm{~min}$

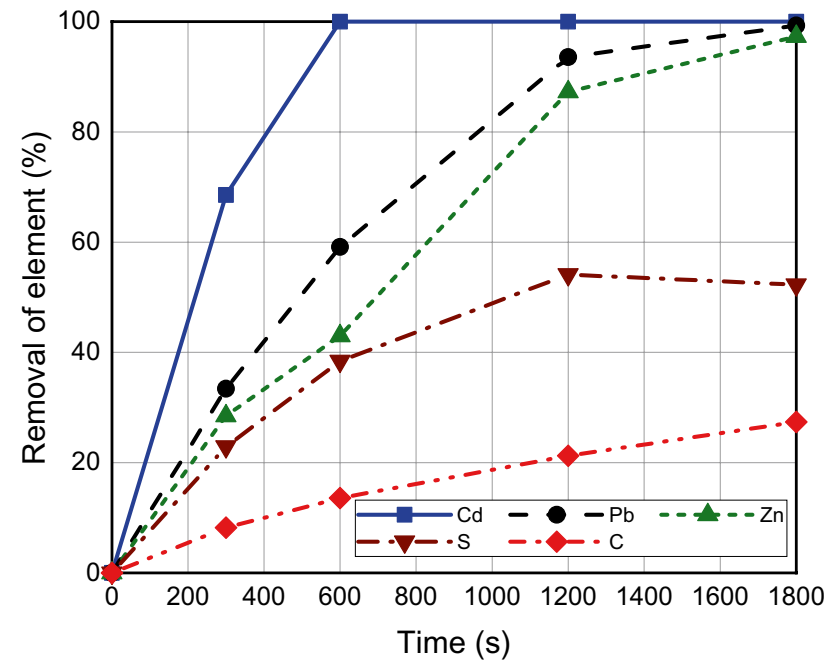

Fig. 8 Loss (wt\%) of various elements from BF dust held over 30 min at $1000{ }^{\circ} \mathrm{C}$ in an inert atmosphere as measured by XRF and LECO analysis

the primary forms of iron remain as $\mathrm{FeO}$ and metallic $\mathrm{Fe}$ (Fig. 7). However, it can also be seen that calcium carbonate reacts with iron oxide to form a calcium ferrite, $\mathrm{Ca}_{2} \mathrm{Fe}_{2} \mathrm{O}_{5}$ (Fig. 7), as previously observed by Robinson [31].

For the BF dust samples, there is quite a dramatic difference between the weight loss behavior at the three temperatures. At $850{ }^{\circ} \mathrm{C}$ it was seen that a plateau in weight loss of between 5 and $8 \%$ was achieved after roughly $2 \mathrm{~min}$ residence time within the furnace. Conversely, after $30 \mathrm{~min}$ at $1000{ }^{\circ} \mathrm{C}, 30 \%$ of the sample mass had been lost and after 5 min at $1300{ }^{\circ} \mathrm{C}, 28 \%$ lost. The additional weight loss can be accounted for by the loss of multiple elements as

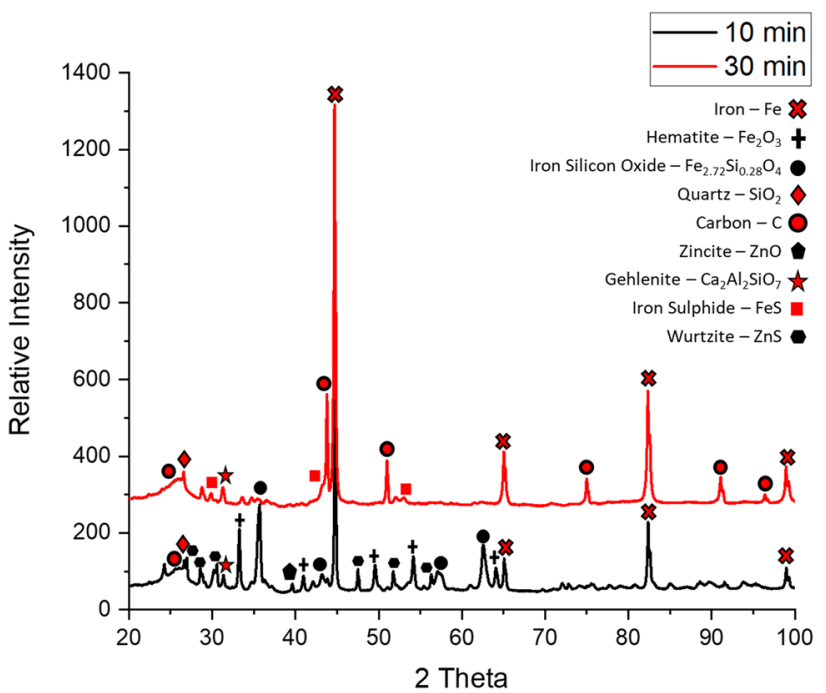

Fig. 9 XRD diffractograms of $\mathrm{BF}$ dust held at $1000{ }^{\circ} \mathrm{C}$ for 10 and $30 \mathrm{~min}$

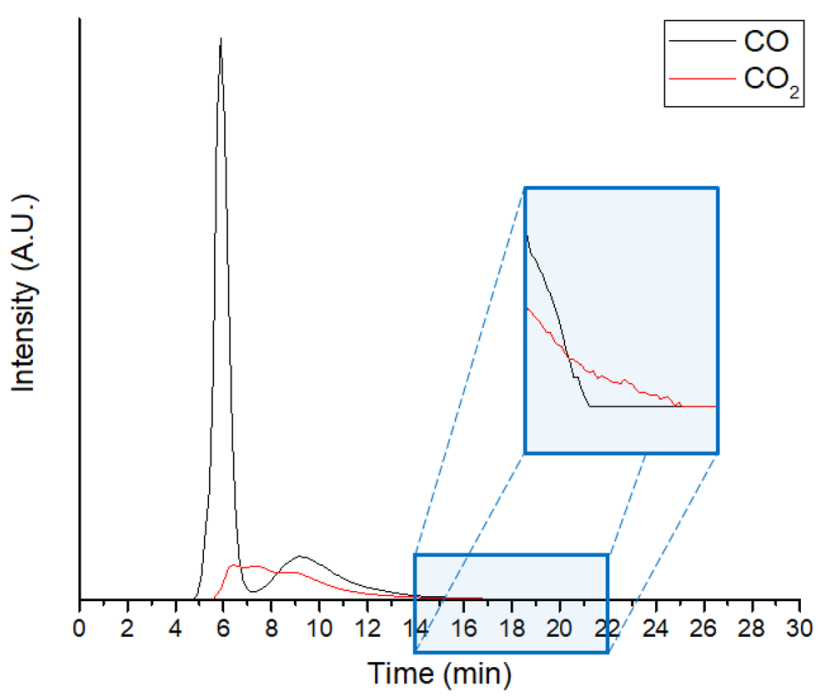

Fig. 10 Off-gas analysis of BF dust held at $1000^{\circ} \mathrm{C}$ for $30 \mathrm{~min}$

indicated by results of XRF analysis of the $1000{ }^{\circ} \mathrm{C}$ sample shown in Fig. 8.

Figure 8 represents the (non-iron) major sources of weight loss in the BF dust samples over 30 min of exposure to $1000{ }^{\circ} \mathrm{C}$ in an inert atmosphere. These values have been measured through analysis of the samples at different time intervals by LECO and XRF analysis. The quantity of carbon has dropped by around $27 \%$ while $\mathrm{Zn}, \mathrm{Cd}$, and $\mathrm{Pb}$ have all been completely removed after $30 \mathrm{~min}$. In the case of cadmium, this is a rapid loss but the $\mathrm{Pb}$ and $\mathrm{Zn}$ require the full time length to be completely removed. Some sulfur is also lost as sulfur oxides. At $1300{ }^{\circ} \mathrm{C}$, these processes occur more rapidly; hence, a plateau in weight loss is reached after only 
5 min. XRD analysis of the 10 and 30 min samples held at $1000^{\circ} \mathrm{C}$ are shown in Fig. 9 .

It can be seen from the diffractograms that both $\mathrm{ZnS}$ and $\mathrm{ZnO}$ are broken down over the $30 \mathrm{~min}$ at $1000{ }^{\circ} \mathrm{C}$. Meanwhile, hematite has undergone partial reduction after $10 \mathrm{~min}$, and the major phase after $30 \mathrm{~min}$ is metallic iron. Peaks in the off-gas analysis of the samples showed the presence of both $\mathrm{CO}$ and $\mathrm{CO}_{2}$ (Fig. 10). This indicates that reactions 1-3 are taking place in the furnace along with others such as reactions $11-13$ using the produced $\mathrm{CO}$ gas. Figure 10 also shows that while more $\mathrm{CO}$ is produced than $\mathrm{CO}_{2}$, the latter is observed over a longer time period, $21 \mathrm{~min}$ after the start of experiment.

$$
\mathrm{Fe}_{3} \mathrm{O}_{4}+\mathrm{CO}_{(\mathrm{g})} \rightarrow 3 \mathrm{FeO}+\mathrm{CO}_{2(\mathrm{~g})} \quad \Delta_{\mathrm{r}} G^{1000^{\circ} \mathrm{C}}=-7 \mathrm{~kJ} \mathrm{~mol}^{-1},
$$

$\mathrm{Fe}_{2} \mathrm{O}_{3}+\mathrm{CO}_{(\mathrm{g})} \rightarrow 2 \mathrm{FeO}+\mathrm{CO}_{2(\mathrm{~g})} \quad \Delta_{\mathrm{r}} G^{1000^{\circ} \mathrm{C}}=-42 \mathrm{~kJ} \mathrm{~mol}^{-1}$,

$\mathrm{FeO}+\mathrm{CO}_{(\mathrm{g})} \rightarrow \mathrm{Fe}+\mathrm{CO}_{2(\mathrm{~g})} \quad \Delta_{\mathrm{r}} G^{1000{ }^{\circ} \mathrm{C}}=9 \mathrm{~kJ} \mathrm{~mol}^{-1}$.

The trends in goethite loss were comparable across the three temperatures tested but reached a greater weight loss plateau at each. Rapid weight loss results in the achievement of weight loss plateaus after $5 \mathrm{~min}$. For $850^{\circ} \mathrm{C}, 1000^{\circ} \mathrm{C}$, and $1300{ }^{\circ} \mathrm{C}$, respectively; the weight loss amounted to $17.5 \%$, $22.5 \%$, and $28 \%$. These high values are primarily due to the large concentration of hydrated species, which are rapidly dehydrated at these temperatures. Also, there are high quantities of sulfur (12.1 wt\%) in the form of sulfates which can be decomposed to some extent at the temperatures studied. XRD analysis shows that after $30 \mathrm{~min}$, both beaverite and $\mathrm{PbSO}_{4}$ have been lost from the sample (Fig. 11). Frost et al.

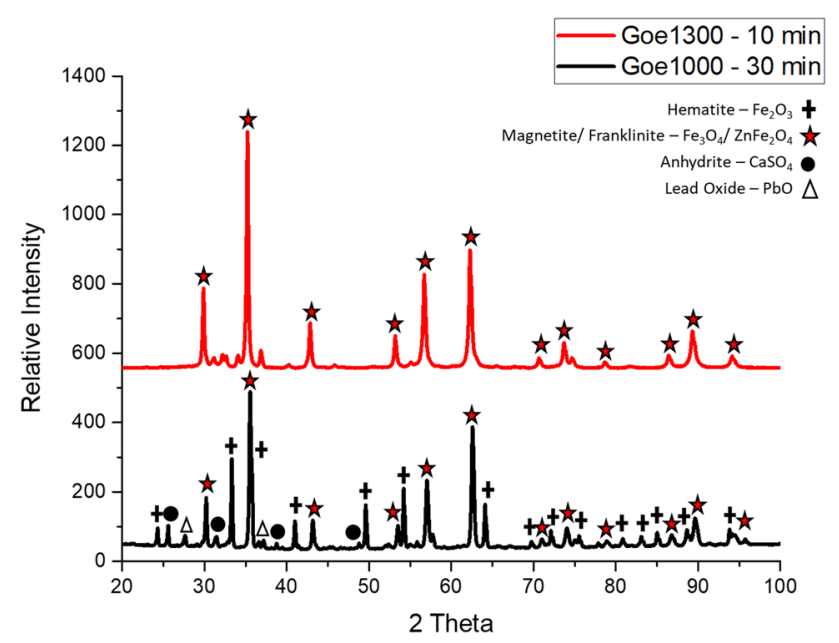

Fig. 11 XRD diffractograms of goethite held at $1000{ }^{\circ} \mathrm{C}$ for $30 \mathrm{~min}$ (black) and at $1300{ }^{\circ} \mathrm{C}$ for $10 \mathrm{~min}$ (red) (color figure online)
(2008) have shown that beaverite will break down in three stages of dehydroxylation, loss of sulfates, and loss of oxygen all before $845^{\circ} \mathrm{C}$ [32]. This will leave a mix of metal oxides in the solid phase and release of lead to the gaseous phase. Meanwhile, $\mathrm{PbSO}_{4}$ has decomposed in order to form $\mathrm{PbO}$ and release sulfur. Gypsum has also dehydrated in order to from anhydrite, $\mathrm{CaSO}_{4}$. From the XRD analysis (Fig. 11), it cannot be said whether franklinite remained as a major phase within the sample due to potential overlap with $\mathrm{Fe}_{3} \mathrm{O}_{4}$. Pickles et al. (2003) state that at high temperatures, franklinite can break down into iron oxide and hematite even in neutral environment [33]. Specifically, they state that this requires temperatures of at least $1227{ }^{\circ} \mathrm{C}$ in order to take place [33]. However, XRF analysis for the samples held for 10 min at $1300{ }^{\circ} \mathrm{C}$ shows minimal loss of zinc in line with that seen at $1000{ }^{\circ} \mathrm{C}$ over $30 \mathrm{~min}$. This indicates that even at temperatures of up to $1300{ }^{\circ} \mathrm{C}$, a reductant is required to break down franklinite.

From the XRD analysis, it can also be observed that the amorphous bumps of ferrihydrite were completely lost at both temperatures. Conversely, strong hematite peaks could be seen in the XRD spectra of goethite held at $1000{ }^{\circ} \mathrm{C}$ but not at $1300^{\circ} \mathrm{C}$. Previous study at lower temperatures showed that at around $300{ }^{\circ} \mathrm{C}$, ferrihydrite can be dehydrated and crystalline hematite structure formed within $2 \mathrm{~h}[34,35]$. Here, it is apparent that the transformation takes place at a much quicker rate, but that it can then be fully broken down to form magnetite at temperatures higher than $1000^{\circ} \mathrm{C}$.

The general observation of iron reduction and zinc loss in the BF dust compared to the goethite and BF dust can be ascribed to the carbon contained acting as a reductant. Here, the carbon will form carbon mono- or dioxide and be lost to the gaseous phase and the oxygen provider will be reduced leading to the loss of volatile species. In order to facilitate the recovery of zinc and enhance the reduction of iron in the goethite and BOF dust, it was proposed to mix them with the BF dust. The carbon contained within the BF dust can then act as a reductant for these purposes. As previously described, a calculation was made to determine how much $\mathrm{BF}$ dust was required to reduce the iron and zinc in the other materials, and further experiments were performed.

\section{Self-reducing Mixtures of Secondary Zinc Sources}

The two-dust mixtures were studied solely at $1000{ }^{\circ} \mathrm{C}$ in three ratios of 20:80, 40:60 and 60:40 BF dust to goethite or BOF dust. The notation used from this point puts the latter component first and describes the ratio with respect to this, i.e., Goe60/40 refers to a sample of mixed goethite/BF dust in a 60:40 ratio. Weight loss was recorded at various retention times over $30 \mathrm{~min}$ for all six samples in two series as shown in Fig. 12. 


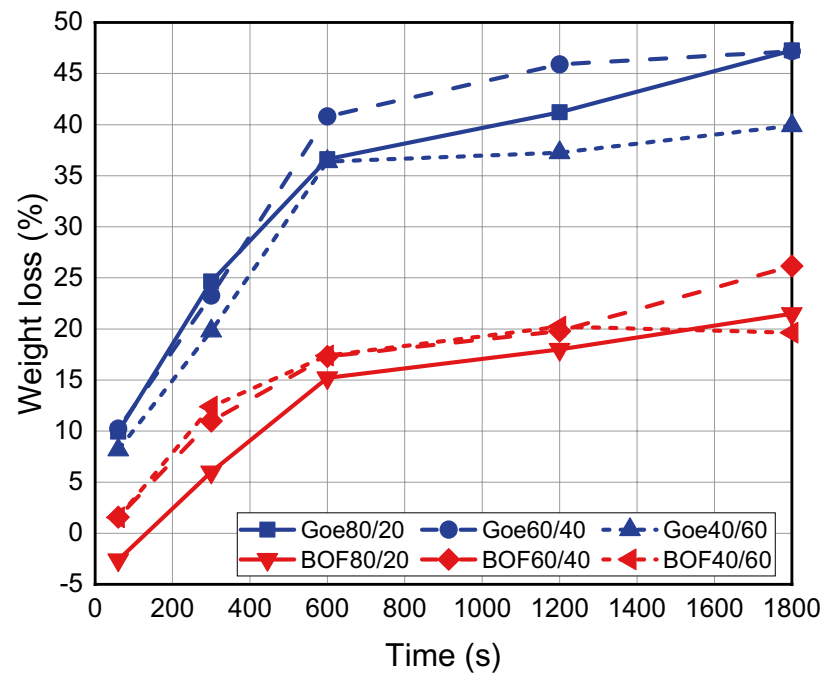

Fig. 12 Weight loss (\%) of industrial waste dusts after holding at $1000{ }^{\circ} \mathrm{C}$ in inert atmosphere over various retention times. Goe80/20 goethite/BF dust mixed in an 80:20 ratio, BOF80/20 BOF/BF dust mixed in an 80:20 ratio

It is clear that there is a great degree of difference in the weight loss between the goethite and BOF dust-containing mixtures. This is due to the relatively larger quantity of volatile, heavy metals in the goethite mixture along with the high sulfur levels. Comparatively, the BOF mixture is still mainly iron oxides (ranging from 53 to $73 \mathrm{wt} \%$ ) with an appreciable quantity of carbon (from 24 to $10 \mathrm{wt} \%$ ) and minimal zinc (3.8 to $1.8 \mathrm{wt} \%$ ). Between the different ratios tested, there is a minimal weight difference for each of the mixtures. For the goethite mixtures, the two that are more concentrated in goethite dust show the greater weight loss (additional 7\%). This was due to the increased presence of sulfate species, hydrated compounds, volatile components, and reducible iron. Minimal difference in weight loss was observed between the BOF mixtures.

\section{Goethite/BF Dust Mixtures}

Both the Goe80/20 and Goe60/40 samples show $90 \%$ loss of zinc after $30 \mathrm{~min}$ of exposure compared to $97.4 \%$ in Goe40/60. It is apparent from Fig. 13 that with longer retention times (around $35 \mathrm{~min}$ ) in the furnace, the majority of the zinc will be lost, dependant on the presence of sufficient reductant.

Elemental and mineralogical analysis was performed on all mixtures but trends are discussed with focus on the 60:40 goethite/BOF dust to BF dust samples. Along with $\mathrm{Zn}$ other elements are lost during the thermal treatment of the samples. Figure 14 gives an example of the percentage removal of other volatile elements that are lost during the treatment of Goe60/40.

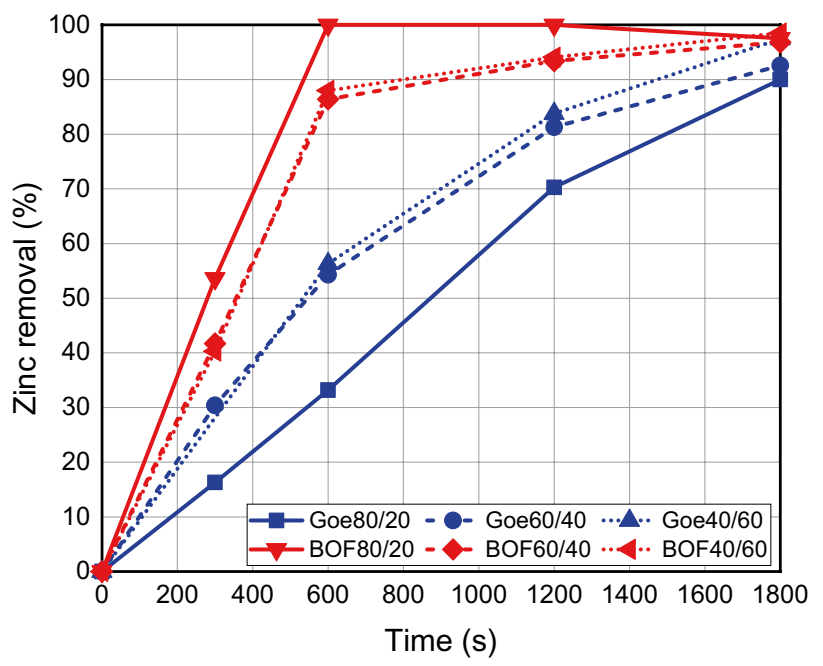

Fig. 13 Weight loss of zinc (\%) from the mixed samples over a 30-min time period. Goe80/20 goethite/BF dust mixed in an 80:20 ratio

From this graph, it can be seen that the carbon concentration (which is initially $18.2 \mathrm{wt} \%$ of the sample) rapidly decreases by around $55 \%$ within 5 min. Following this, a plateau is achieved after 10 min with around $75-80 \%$ of the carbon lost to the gaseous phase. Similarly, in the case of the Goe $40 / 60$ sample, around $60-65 \%$ carbon removed after 10 min of testing. However, for the Goe80/20 mixture, the trend is different; after $10 \mathrm{~min}, 75 \%$ of the carbon has been removed from the sample, while at $30 \mathrm{~min}, 95 \%$ has been lost. Coupling this to the previous observation of incomplete zinc weight loss, it is apparent that there is most likely insufficient reductant for complete reduction and, hence,

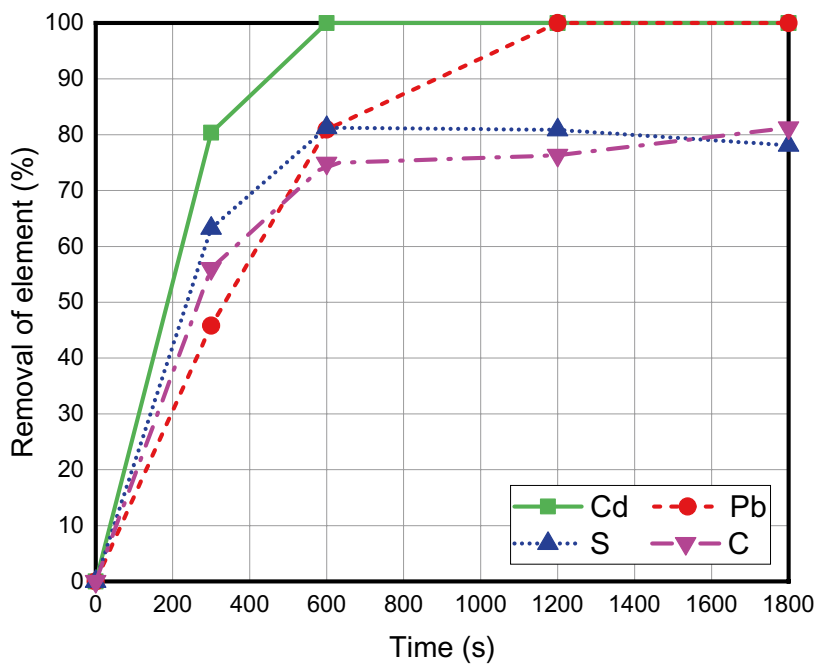

Fig. 14 Removal of volatile elements from Goe60/40 over $30 \mathrm{~min}$ at $1000{ }^{\circ} \mathrm{C}$ as measured by XRF/LECO 
vaporization of zinc. This indicates that the reduction of zinc should be complete at time lengths longer than $30 \mathrm{~min}$ for Goe60/40 but not Goe80/20. This differing behavior is to be expected between the two mixtures as it was previously predicted that insufficient carbon would be present in the Goe80/20 sample while Goe60/40 had a slight excess. Also, as predicted, Goe40/60 is over-enriched in carbon, despite complete reduction of zinc, there is still $35-40 \%$ of the initial carbon remaining in the sample.

The behavior of other elements shown in Fig. 14 is highly consistent across the ratio of dusts tested. In all samples, $\mathrm{Cd}$ and $\mathrm{Pb}$ were completely lost to the gaseous phase within

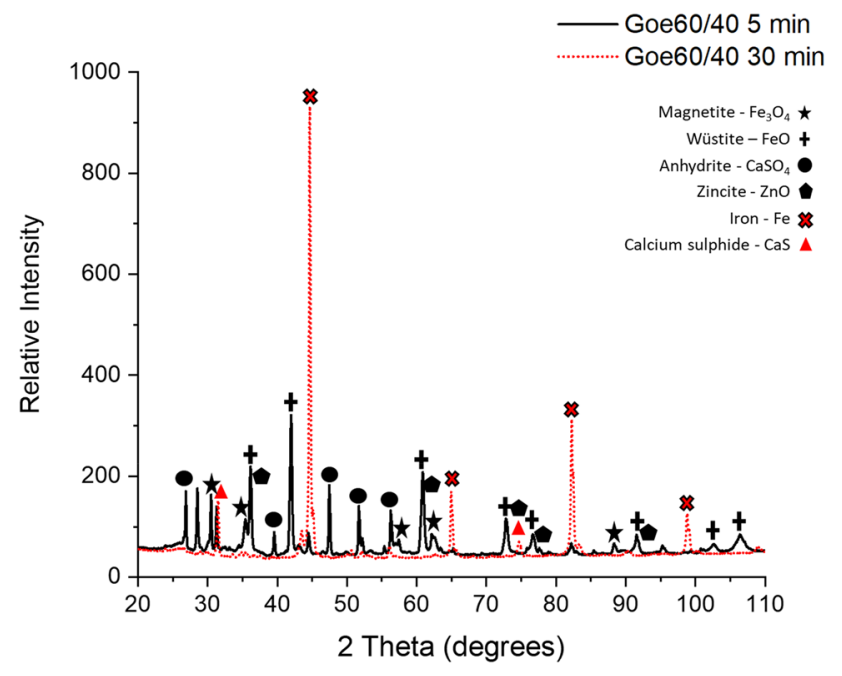

Fig. 15 XRD diffractograms of goethite/BF dust in a 60:40 mixture after $5 \mathrm{~min}$ and $30 \mathrm{~min}$ residence time at $1000{ }^{\circ} \mathrm{C}$ under inert atmosphere. Black symbols represent 5 min phases, red are 30 min phases, and red with black outlines are present in both (color figure online)
10 and 20 min exposure at $1000{ }^{\circ} \mathrm{C}$, respectively. Despite the starting concentration of $\mathrm{S}$ varying between samples, there was a reasonably consistent quantity lost after 10 and 30 min (between 75 and 85\%). XRD analysis shows that by 5 min, both beaverite and $\mathrm{PbSO}_{4}$ have been lost from the sample (Fig. 15). Beaverite will be lost in a similar way as described previously for the individual BOF sample. Meanwhile, $\mathrm{PbSO}_{4}$ can react to form other sulfates such as $\mathrm{CaSO}_{4}$ (Reaction 6) or decompose to release $\mathrm{Pb}$ and $\mathrm{SO}_{x}$ to the gaseous phase (as indicated in Fig. 14). The final form of sulfur identified by XRD is that initially of gypsum. From Fig. 6, it can be seen that after 5 min, dehydration of the gypsum has occurred and after $30 \mathrm{~min}, \mathrm{CaSO}_{4}$ has reacted to form $\mathrm{CaS}$. This remaining $\mathrm{CaS}$ can explain the retention of some sulfur in the samples.

The XRD diffractogram shown in Fig. 15 for the Goe60/40 mixture indicates clearly the reduction of iron oxide, with sharply growing peaks of metallic iron from 5 to $30 \mathrm{~min}$ reaction. While the initial sample contained ferrihydrite, franklinite, and hematite (Table 4), the 5 min sample already shows reduction to magnetite, wüstite, and some metallic iron. From the XRD spectrum, no bumps indicative of the presence of amorphous phases such as ferrihydrite were observed. By $30 \mathrm{~min}$, the sample appears to be mostly metallic iron. To further probe the reduction of iron-bearing species, Mössbauer spectroscopy was employed, and the results are presented in Table 5 and Fig. 16.

The Mössbauer results show great similarity to those collected through XRD analysis. After $5 \mathrm{~min}$, the goethite mixture has undergone reduction reactions with the contained carbon and the produced $\mathrm{CO}$. The initial composition is composed of franklinite, magnetite, and ferrihydrite with iron prominently in the $\mathrm{Fe}^{3+}$ oxidation state.
Table 5 The Mössbauer fitted parameters of mixed dust samples obtained at $300 \mathrm{~K}$

\begin{tabular}{llllllc}
\hline Sample/treatment & IS $\left(\mathrm{mm} \cdot \mathrm{s}^{-1}\right)$ & $\mathrm{QS}\left(\mathrm{mm} \cdot \mathrm{s}^{-1}\right)$ & $\begin{array}{l}\text { Hyperfine } \\
\text { field (T) }\end{array}$ & $\Gamma\left(\mathrm{mm} \cdot \mathrm{s}^{-1}\right)$ & Phase & $\begin{array}{l}\text { Spectral } \\
\text { contribution } \\
(\%)\end{array}$ \\
\hline Goe60/40 5 min & 0.94 & 0.75 & - & 0.66 & $\mathrm{Fe}^{2+}\left(\mathrm{Fe}_{1-x} \mathrm{O}\right)$ & 76 \\
& 0.28 & -0.02 & 49.2 & 0.40 & $\mathrm{Fe}_{3} \mathrm{O}_{4}(\mathrm{I})$ & 8 \\
& 0.71 & -0.03 & 45.2 & 0.90 & $\mathrm{Fe}_{3} \mathrm{O}_{4}(\mathrm{II})$ & 16 \\
Goe60/40 30 min & 0.00 & 0.00 & 33.2 & 0.43 & $\mathrm{Fe}^{0}$ & 92 \\
& 0.35 & 0.93 & - & 0.52 & $\mathrm{Fe}^{3+}$ & 8 \\
BOF60/40 5 min & 0.00 & 0.00 & 33.0 & 0.32 & $\mathrm{Fe}^{0}$ & 32 \\
& 0.36 & 0.84 & - & 0.35 & $\mathrm{Fe}^{3+}$ & 7 \\
& 0.96 & 0.91 & - & 0.74 & $\mathrm{Fe}^{2+}\left(\mathrm{Fe}_{1-x} \mathrm{O}\right)$ & 48 \\
& 0.31 & -0.02 & 48.9 & 0.54 & $\mathrm{Fe}_{3} \mathrm{O}_{4}(\mathrm{I})$ & 5 \\
& 0.67 & 0.00 & 45.5 & 0.75 & $\mathrm{Fe}_{3} \mathrm{O}_{4}(\mathrm{II})$ & 8 \\
BOF60/40 30 min & 0.00 & 0.00 & 33.2 & 0.39 & $\mathrm{Fe}^{0}$ & 81 \\
& 0.31 & 0.77 & - & 0.56 & $\mathrm{Fe}^{3+}$ & 9 \\
& 0.77 & 1.70 & - & 0.74 & $\mathrm{Fe}^{2+}\left(\mathrm{Fe}_{1}-{ }_{x} \mathrm{O}\right)$ & 10 \\
\hline
\end{tabular}

Experimental uncertainties: isomer shift, IS $\pm 0.02 \mathrm{~mm} \mathrm{~s}^{-1}$; quadrupole splitting, $\mathrm{QS} \pm 0.02 \mathrm{~mm} \mathrm{~s}^{-1}$; line width, $\Gamma \pm 0.03 \mathrm{~mm} \mathrm{~s}^{-1}$; hyperfine field $\pm 0.1 \mathrm{~T}$; spectral contribution $\pm 3 \%$ 


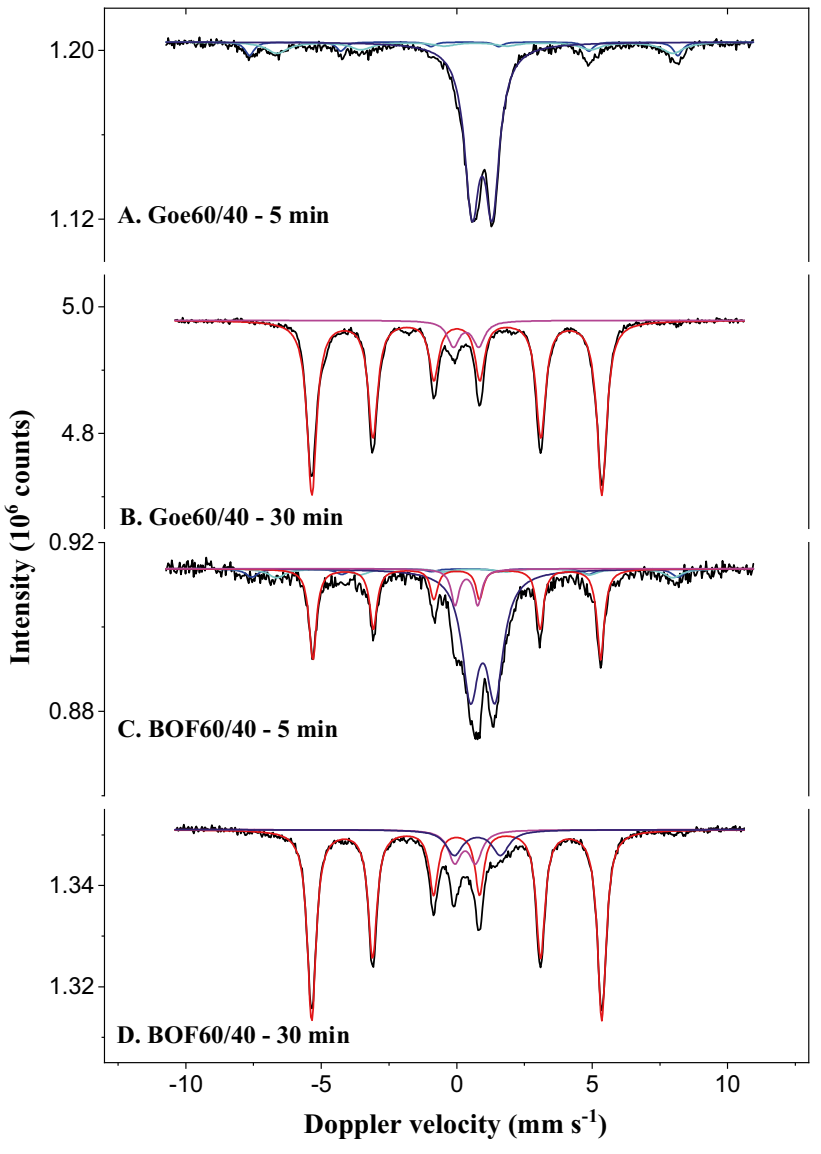

Fig. 16 Mössbauer spectra obtained at $300 \mathrm{~K}$ of mixed samples

However, after just $5 \mathrm{~min}, 76 \%$ of the iron content is in the $\mathrm{Fe}^{2+}$ oxidation state in the form of wüstite. Beyond this, the remainder is made up of magnetite with no franklinite observable. Furthermore, after 30 min residence time in the furnace, further reduction has taken place to the extent that $92 \%$ is in the metallic iron form and only $8 \%$ is present in the $\mathrm{Fe}^{3+}$ form. This $\mathrm{Fe}^{3+}$ could not be ascribed to a specific iron oxide through either Mössbauer spectroscopy or $\mathrm{XRD}$ analysis. Consequently, $30 \mathrm{~min}$ exposure to $1000^{\circ} \mathrm{C}$ in an inert atmosphere is enough time for self-reduction of the sample to take place and the great majority of the iron to be in the metallic form.

The lack of franklinite after 5 min coupled to the presence of $\mathrm{ZnO}$ in the sample diffractogram (Fig. 15) indicates the rapid breakdown of the former. This is facilitated by the presence of a carbon-based reductant to reduce the zinc ferrite and to produce $\mathrm{CO}$ or $\mathrm{CO}_{2}$ and zinc oxide (i.e., Reaction 4). The rapid kinetics of this carbothermic breakdown have been described previously [36]. Conversely, the breakdown of the zinc oxide (Reaction 5) necessitates the remainder of the retention time in the furnace. After

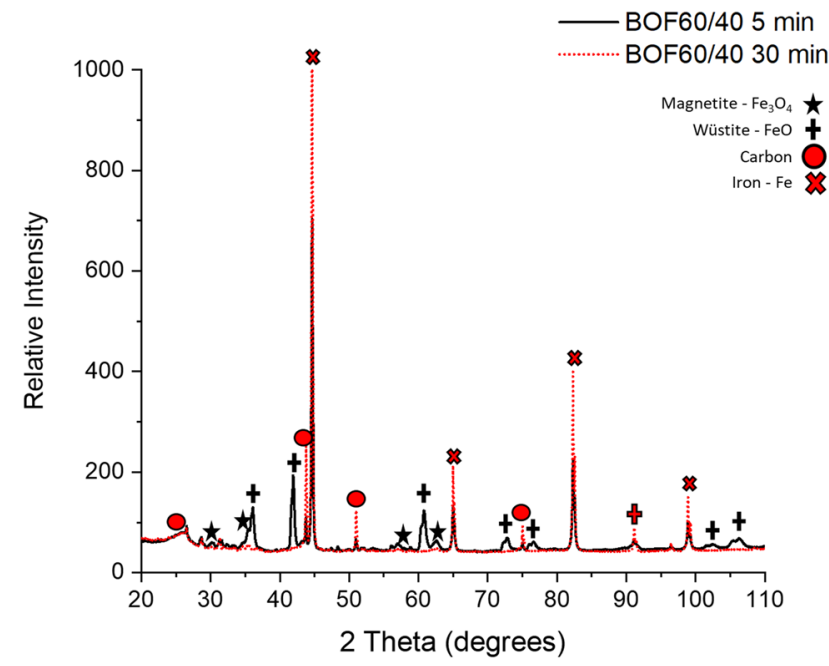

Fig. 17 Diffractograms of BOF/BF dust in a 60:40 mixture after 5 and $30 \mathrm{~min}$ residence time at $1000{ }^{\circ} \mathrm{C}$ under $\mathrm{N}_{2}$. Black symbols represent $5 \mathrm{~min}$ phases and red with black outlines are present in both (color figure online)

$30 \mathrm{~min}$, it is no longer observable in the X-ray diffractogram (Fig. 15).

All ratios of dusts appeared to show similar behavior. However, it has been shown that the Goe80/20 sample contained insufficient carbon to fully reduce the contained zinc and iron oxides. As such, it can be predicted that a mixture of minimum $30 \%$ BF dust to $70 \%$ goethite should be utilized to benefit from the reducing impact of the contained carbon.

\section{BOF/BF Dust Mixtures}

The BOF/BF dust mixtures show lower initial concentration of zinc than the goethite equivalents but higher quantities of iron. Figure 13 shows that within $10 \mathrm{~min}$, all of the zinc has been removed from BOF80/20 and a large proportion has been lost from BOF60/40 and BOF40/60. Furthermore, after 30 min holding at $1000{ }^{\circ} \mathrm{C}$, the zinc in the latter two mixtures has effectively been entirely lost to the gas phase. There was minimal presence of $\mathrm{Pb}$ in these samples (maximum $0.8 \mathrm{wt} \%$ ), and this was all lost within $10 \mathrm{~min}$. Sulfur was similarly present in lower concentration (maximum 2.2 wt $\%$ ) and showed a loss of between 60 and $75 \%$ over the course of the $30 \mathrm{~min}$ residence time. Mineralogy was studied using XRD and is shown in Fig. 17.

It can be seen that there is carbon present in both the $5 \mathrm{~min}$ and $30 \mathrm{~min}$ samples. In fact, in all the ratios tested, a great amount of carbon was remaining, from 41 to $237 \mathrm{mg} \mathrm{g}^{-1}$. Moreover, the XRD appears to show that after 30 min, only metallic iron was remaining. In order to check this Mössbauer spectroscopy was recorded (Table 5) and iron-bearing phases investigated. These results mostly 
aligned with that obtained with XRD analysis. After $5 \mathrm{~min}$, multiple iron phases are present with the largest proportion being $\mathrm{FeO}(48 \%)$ followed by metallic $\mathrm{Fe}(32 \%)$. Beyond this, magnetite was also present in small quantity (13\%) along with a general $\mathrm{Fe}^{3+}$ oxide peak (7\%). It is apparent that iron carbide $\left(\mathrm{Fe}_{3} \mathrm{C}\right)$, present in the initial material (Table 4), has decomposed. This has previously been studied and shown to result in the generation of $\mathrm{C}$ and $\mathrm{Fe}$ [37]. The reduction reaction continues over the remaining residence time and by $30 \mathrm{~min}, 81 \%$ is metallic iron. The remainder is $10 \% \mathrm{FeO}$ and $9 \%$ an $\mathrm{Fe}^{3+}$ oxide, once again this latter phase could not be identified definitively through Mössbauer or XRD analysis. The combination of these results with the LECO findings of carbon content and XRF of zinc suggests that there is sufficient carbon present to fully reduce the valuable iron and zinc components. For fabrication of a granulate or briquette mixture of these components, a mixture in the ratio of 80:20 BOF to BF dust should be sufficient, potentially even less $\mathrm{BF}$ dust is required, but in this case, the quantity of zinc becomes increasingly low.

\section{Concluding Remarks}

The behavior of waste materials generated by the zinc and ironmaking industry has been pyrometallurgically studied.

During studies of individual samples, it was observed that BOF dust and goethite underwent minimal loss of zinc and reduction of iron. This was due to the lack of reductant to drive the reactions. Conversely, BF dust showed complete reduction of iron oxides to metallic iron and total conversion of zinc to the gas phase due to contained carbon. Consequently, it was decided to mix goethite/BOF dust with $\mathrm{BF}$ dust for further studies. All three mixtures of BOF dust with BF dust (80:20, 60:40, and 40:60 ratios) showed complete removal of zinc along with significant reduction of iron. The reduction and vaporization of zinc were achieved within around $15 \mathrm{~min}$ residence time but the full $30 \mathrm{~min}$ was required for the iron oxide to be fully reduced. Other volatiles are lost along with a large proportion of the contained sulfur. In the mixtures of goethite with BF dust, the ratio of 80:20 proved to be slightly under-concentrated in carbon. Despite this, the large majority of the zinc $(90 \%)$ has been removed from the sample. For the samples in ratios of 60:40 and 40:60, BOF to BF dust sufficient carbon was present and full reduction of iron oxides could be achieved.

Despite the vastly complex and varying compositions of these waste materials, once mixed with a reductant the removal of zinc and reduction of iron oxides to metallic iron could be achieved. In order to provide sufficient carbon for full reduction of the iron and zinc, the proposed ratio of dusts is $30: 70 \mathrm{BF}$ dust to goethite and 20:80 BF to BOF dust. These mixtures can be utilized within the HIsarna furnace in order to facilitate the recovery of valuable material. By utilizing carbon that was lost as a waste in BF dust, the requirement of using 'new' coal can be reduced and the environmental impact of the process can be minimized. The metallic iron can be utilized in the production of steel while the zinc can be utilized as a secondary raw material by the zinc industry.

Acknowledgements ReclaMet research has been supported by EIT RawMaterials Funding (Project 17209) through the theme of "Increased resource efficiency in mineral and metallurgical processes" as part of Segment D2.2 Upscaling. We would like to acknowledge Ruud Hendrikx and Richard Huizenga at the Department of Materials Science and Engineering of the Delft University of Technology for the X-ray analyses.

\section{Declarations}

Conflict of interest On behalf of all authors, the corresponding author states that there is no conflict of interest.

Open Access This article is licensed under a Creative Commons Attribution 4.0 International License, which permits use, sharing, adaptation, distribution and reproduction in any medium or format, as long as you give appropriate credit to the original author(s) and the source, provide a link to the Creative Commons licence, and indicate if changes were made. The images or other third party material in this article are included in the article's Creative Commons licence, unless indicated otherwise in a credit line to the material. If material is not included in the article's Creative Commons licence and your intended use is not permitted by statutory regulation or exceeds the permitted use, you will need to obtain permission directly from the copyright holder. To view a copy of this licence, visit http://creativecommons.org/licenses/by/4.0/.

\section{References}

1. Besta P, Janovská K, Samolejová A et al (2013) The cycle and effect of zinc in the blast-furnace process. Metalurgija 52:197-200

2. Geerdes M, Chaigneau R, Kurunov I, Lingiardi O, Ricketts J (2015) Modern blast furnace ironmaking. IOS Press, Amsterdam

3. Lanzerstorfer C, Angerbauer A, Gaßlbauer M (2018) Feasibility of air classification in dust recycling in the iron and steel industry. Steel Res Int 89:1-6

4. Omran M, Fabritius T (2019) Utilization of blast furnace sludge for the removal of zinc from steelmaking dusts using microwave heating. Sep Purif Technol 210:867-884

5. Mathieux F, Ardente F, Bobba S et al (2017) Critical raw materials and the circular economy. Background report. Rep EUR 28832 EN

6. Meylan G, Reck BK (2017) The anthropogenic cycle of zinc: status quo and perspectives. Resour Conserv Recycl 123:1-10

7. Lanzerstorfer C (2018) Electric arc furnace (EAF) dust: application of air classification for improved zinc enrichment in in-plant recycling. J Clean Prod 174:1-6

8. Kuwauchi Y, Barati M (2012) Model for the carbothermic reduction of dust-carbon composite agglomerates. In: AISTech iron and steel technology conference proceedings, vol 53, pp 143-152 
9. Antrekowitsch J, Rösler G, Steinacker S (2015) State of the art in steel mill dust recycling. Chem Ing Tech 87:1498-1503

10. Claassen J (2006) Characterisation and optimisation of the Zincor iron removal process. Thesis, University of Pretoria

11. Ma N-Y (2011) On in-process separation of zinc from EAF dust. In: EPD congress, pp 947-952

12. Meijer K, Zeilstra C, Teerhuis C et al (2014) The HIsarna ironmaking process 1. In: European steel environment and energy congress, $\mathrm{p} 23$

13. Xu J, Xin J, Wang N, et al (2018) Kinetic analysis of blast furnace dust recycling with flash reduction process at high temperature. In: 9th International Symposium on High-Temperature Metallurgical Processing, Springer, Cham, pp 753-763

14. Mombelli D, Di Cecca C, Mapelli C et al (2016) Experimental analysis on the use of BF-sludge for the reduction of BOF-powders to direct reduced iron (DRI) production. Process Saf Environ Prot 102:410-420

15. Machado JGMS, Brehm FA, Moraes CAM et al (2006) Chemical, physical, structural and morphological characterization of the electric arc furnace dust. J Hazard Mater 136:953-960

16. Vereš J, Šepelák V, Hredzák S (2015) Chemical, mineralogical and morphological characterisation of basic oxygen furnace dust. Miner Process Extr Metall 124:1-8

17. Klencsár Z (1997) Mössbauer spectrum analysis by evolution algorithm. Nucl Instrum Methods Phys Res B 129:527-533

18. Roine A (2002) Outokumpu HSC chemistry for Windows: chemical reaction and equilibrium software with extensive thermochemical database. User's guide

19. Omran M, Fabritius T, Yu Y, Chen G (2020) Thermal and mass spectroscopic analysis of BF and BOF sludges: study of their behavior under air and inert atmosphere. Metals 10:397

20. Romero M, Rincón JM (1997) Microstructural characterization of a goethite waste from zinc hydrometallurgical process. Mater Lett 31:67-73

21. Pelino M, Cantalini C, Rincon JM (1997) Preparation and properties of glass-ceramic materials obtained by recycling goethite industrial waste. J Mater Sci 32:4655-4660

22. Veres J (2014) Determination of zinc speciation in metallurgical wastes by various analytical methods. Int J Chem Environ Eng Determ 5:5

23. Schrama FNH, Beunder EM, Van den Berg B et al (2017) Sulphur removal in ironmaking and oxygen steelmaking. Ironmak Steelmak 44:333-343

24. Nedar L (1996) Dust formation in a BOF converter. Steel Res $8: 320-327$
25. Kukkadapu RK, Zachara JM, Fredrickson JK et al (2003) Transformation of 2-line ferrihydrite to 6-line ferrihydrite under oxic and anoxic conditions. Am Mineral 88:1903-1914

26. Loan M, Parkinson G, Newman M, Farrow J (2002) Iron oxyhydroxide crystallization in a hydrometallurgical residue. J Cryst Growth 235:482-488

27. Schwertmann U, Cornell RM (1991) Iron oxides in the laboratory: preparation and characterization. Wiley, Weinheim

28. Bigham JM, Schwertmann U, Traina SJ et al (1996) Schwertmannite and the chemical modeling of iron in acid sulfate waters. Geochim Cosmochim Acta 60:2111-2121

29. Rodriguez Rodriguez N, Machiels L, Onghena B et al (2020) Selective recovery of zinc from goethite residue in the zinc industry using deep-eutectic solvents. RSC Adv 10:7328-7335

30. Cantarino MV, De Carvalho FC, Borges Mansur M (2012) Selective removal of zinc from basic oxygen furnace sludges. Hydrometallurgy 111-112:124-128

31. Robinson R (2005) High temperature properties of by-product cold bonded pellets containing blast furnace flue dust. Thermochim Acta 432:112-123

32. Frost RL, Locke AJ, Martens W (2008) Thermal analysis of beaverite in comparison with plumbojarosite. J Therm Anal Calorim 92:887-892

33. Pickles CA (2003) Reaction of electric arc furnace dust with molten iron containing carbon. Miner Process Extr Metall 112:81-89

34. Vempati RK, Loeppert RH, Sittertz-Bhatkar H, Burghardt RC (1990) Infrared vibrations of hematite formed from aqueous- and dry-thermal incubation of Si-containing ferrihydrite. Clays Clay Miner 38:294-298

35. Stanjek H, Weidler PG (1992) The effect of dry heating on the chemistry, surface area, and oxalate solubility of synthetic 2-line and 6-line ferrihydrites. Clay Miner 27:397

36. Lee JJ, Lin CI, Chen HK (2001) Carbothermal reduction of zinc ferrite. Metall Mater Trans B 32:1033-1040

37. Miki T, Ishii K (2014) Decomposition behavior of Fe3C under $\mathrm{Ar}$ atmosphere. ISIJ Int 54:29-31

Publisher's Note Springer Nature remains neutral with regard to jurisdictional claims in published maps and institutional affiliations. 